\title{
THE ROCK-CARVED TUMULUS OF NIKON IN TISNA
}

\author{
Tisna'daki Nikon’un Kaya-Oygu Tümülüsü \\ Özden ÜRKMEZ \\ İzmir Demokrasi Üniversitesi, Sosyal Bilimler Enstitüsü, \\ Arkeoloji Anabilim Dalı, Doç. Dr. \\ ozdenurkmez@gmail.com \\ Orcid ID: 0000-0003-4213-3497
}

\section{Abstract}

Tisna, one of the lesser-known ancient cities of the Aeolis region, has been studied in detail since 2018 . The first studies carried out in the region since the end of the 19th century localized the region in the Kocakale Tepe - Sarkkale Tepe - Mantar Tepe triangle as Tisna. It is understood that the center of the city is Sarıkale Tepe. The name Tisna first appears on the coins of the 4th century BC in the region. From the Roman era, the city is called Titanus. One of the most important features of the city is that it is surrounded by necropoleis. There are different types of tombs in the necropoleis, especially located on the southern and western slopes. One of these tomb types is the Tumuli. However, as a result of our investigation, it was understood that these tumuli had a different structure from the classic tumuli. We named this type of tomb, in which a rock tomb is covered with a masonry hill, the Rock-Carved Tumulus. The subject of this article is Nikon's rock-carved tumulus, which is understood to be one of such tombs in the region. Our evaluations on the tomb, which has a unique feature in terms of construction technique, indicate that it must belong to the Late Classical period, perhaps to the early 4 th century.

Keywords: Aeolis, Tisna, Necropolis, Classical Period, Tumulus, Rock-Carved Tumulus.
Özet

Aiolis bölgesinin az bilinen antik kentlerinden biri olan Tisna, 2018 yılından itibaren ayrıntılı olarak çalışılmaya başlanmıştır. 19 yüzyılın sonundan itibaren bölgede yapılan ilk çalışmalar, Kocakale Tepe - Sarıkale Tepe - Mantar Tepe üçgenindeki bölgeyi Tisna olarak lokalize edilmiştir. Kentin merkezinin ise Sarıkale Tepe olduğu anlaşılmaktadır. Tisna adı ilk kez bölgedeki 4 . Yüzyıl sikkelerinde karşımıza çıkar. Roma çağından itibaren ise kent Titanus olarak adlandırılır. Kentin en önemli özelliklerinden biri etrafının nekropolislerle çevrili olmasıdır. Özellikle güney ve batı yamaçlarda konumlanan nekropolislerde farklı türdeki mezarlar yer alır. Bu mezar türlerinden biri de Tümülüslerdir. Fakat bizim incelememiz sonucunda bu Tümülüslerin klasik Tümülüslerden farklı bir yapıya sahip olduğu anlaşılmıştır. Bir kaya mezarının üzerinin yığma tepeyle kapatıldığ mezar türüne biz Kaya-Oygu Tümülüs ismini verdik. Bu makelenin konusu bölgedeki bu tür mezarlardan biri olduğu anlaşılan Nikon'un kaya-oygu tümülüsüdür. İnşa tekniği açısından ünik bir özelliğe sahip mezar üzerinde yaptığımız değerlendirmeler, onun Geç Klasik döneme belki de erken 4. Yüzyıla ait olması gerektiğine işaret eder.

Anahtar Kelimeler: Aiolis, Tisna, Nekropolis, Klasik Dönem, Tümülüs, Oygu Kaya Tümülüsü. 

mention this name is Plinius ${ }^{1}$. According to the information he gave, the city located in the south of Gryneion, one of the cities of Aeolis, took its name from the Titanus river. Again, according to him, the name of this city is Titanus. However, numerous 4th century coins from the region prove that the real name of the settlement was Tisna. Apparently, the name Tisna was forgotten by the first century BC. The first attempts to localize Tisna were made by Guichon, who came to the region after $1860^{2}$.Later studies were done by Sayce ${ }^{3}$, Schuchhardt ${ }^{4}$, and Conze ${ }^{5}$, respectively, in the late 19th and early 20th centuries. In particular, because of Conze's studies, the region in the Kocakale Tepe Sarıkale Tepe - Mantar Tepe triangle has been localized as Tisna. The studies started by Erdan and his team since 2018 have shown that the city of Tisna should be exactly Sarıkale Tepe ${ }^{6}$. Both the reports and publications of ancient travelers and archaeologists and the research carried out by our team in the recent period present the settlement as a city of necropoleis. The subject of this article is a special tomb in the necropolis, which covers the southern and western slopes of the acropolis and is understood to consist of hundreds of tombs ${ }^{7}$.

\section{The Geography of Tisna and the South/Western Necropolis}

The research carried out in Tisna/Sarıkale Tepe, in the light of the ceramic finds, show that the city was founded circa at least $2000 \mathrm{BC}^{8}$. So, what is the geological situation in 4000 years of Tisna and its surroundings? In this regard, especially the studies of Özşahin -Eroğlu ${ }^{9}$ and Vardar ${ }^{10}$ have provided important answers to this issue. Accordingly, Sarkkale Tepe, which is $179 \mathrm{~m}$ above sea level, was built on an elevation in volcanic terrain. The region is composed of Andesite, Basalt and Tuff type rocks. It is seen that the Tisna acropolis is a basalt elevation. The main territory around it consists of wide tuff slopes. Geological studies in the region have shown that the western, northern, and southern sides of the Tisna elevation are covered with an alluvial fill. The most important architect of this situation is the Güzelhisar/Tisnaios river, which gives its name to the city, and many other streams around. In fact, this filling extends to the borders of Uzunhasanlar Village in the south. Especially Vardar's studies show that Myrina, where the Tisnaios river empties into the sea, was an island about 5000 years ago and it shows that it started to be connected to the mainland by alluvial filling around $2000 \mathrm{BC}$. In addition, a mound

\footnotetext{
${ }^{1}$ Plinius. Nat. 5.49 .

${ }^{2}$ For Guichon see. Reviews on Chronique d'Orient 1891: Erdan 2019, 8.

${ }^{3}$ Sayce 1882, 222.

${ }^{4}$ Schuchhardt 1887, 1213; Schuchhardt 1912, 102-103.

${ }^{5}$ Conze 1910.

${ }^{6}$ Erdan 2019.

${ }^{7}$ I would like to thank the Tisna team, which I have joined since the 2021 season, and Emre Erdan, the head of research for inviting me to this team.

${ }^{8}$ Erdan 2019, Kat.no: 1.

9 Özşahin-Eroğlu 2019.

${ }^{10}$ Vardar 2018.
} 
identified in the middle of the alluvial plain in the west of Aliağa Organized Industrial Zone indicates that the sea formed a coastal line around the present North Aegean Highway 5000 - 6000 years ago. This coastline probably was more inside $2 \mathrm{~km}$ from Myrina in the second millennium BC. However, according to our observations, Tisnaios was forming a bridge up to $1 \mathrm{~km}$ north-west of Sarıkale Tepe so that the ships could move freely. Perhaps even a natural inner harbor belonging to the city can be mentioned at this point until the Early Iron Age. As a result, the rock city of Tisna was a citadel connected by the sea with Tisnaios. And it is understood that a significant part of the slopes of this citadel consists of hundreds of tombs. At this point, the large tuff rocky especially forming the southern and western slopes appears as a complete necropolis area (Fig.1).

Detected for the first time in 2019 and named as "Sarıkale Tepe South Slope Necropolis" by researchers, the necropolis covers an area of approximately 10 hectares. The surveys and the ceramics in the area, show that the necropolis was first used in the 7th century BC. However, according to our current findings, the necropolis was used extensively in the 6th century $\mathrm{BC}$, and then its use ended. In the examination carried out by us in 2021, it was seen that most of the hundreds of tombs that make up this necropolis are of a kind of "chamosorion" type ${ }^{11}$. On the other hand, the necropoleis of Tisna/Sarıkale Tepe are not limited to the southern slope. Our findings show that all the slopes are full of graves. Among these tombs, there are tumuli in the form of stacked hills. One of them is the tumulus number 1, which is in the west of the city but has a connection with the southern necropolis.

\section{Nikon's Rock-Carved Tumulus}

A tumulus is generally formed by covering a wooden or stone room designed for the burial of the dead with a cone-shaped soil. The result is a small, large, or gigantic hill. This tradition, which extends from the Balkans in the west to Central Asia in the east, goes back to the Bronze Age ${ }^{12}$. This type of tomb spread over the wide Eurasian geography is sometimes called "Kurgan" depending on the region it is located. In the case of Anatolia, it is seen that this tradition was brought to the region by the Phrygians in the Early Iron Age and the first examples were created because of piling up soil on a wooden burial chamber ${ }^{13}$. The spread of the tradition was mainly during the Lydian Kingdom. The earliest Tumulus tombs in Central Lydia (around Sardis) not was before 600 BC. Also, the rock tombs are also not dated before that. Considering that the Lydian tumuli also had stone chambers, it would be correct to attribute this to iron tools. Considering the architectural condition of more than 500 tumuli identified in Lydia, there are stone walls surrounding the main tomb. In other words, the burial was protected by walls and soil was piled up on this area ${ }^{14}$. Huge tumuli in Sardis, which belong to Gyges and Alyattes, dated to the

\footnotetext{
${ }^{11}$ For this necropolis, see in detail: Erdan-Aydoğmuş 2019, 1131-1157.

${ }^{12}$ Ronchetta 2016, 515.

${ }^{13}$ Sams 2007, 49.

${ }^{14}$ For Lydia Tumulus and Rock Tombs, see. Baughan 2010, 273-276.
} 
first half of the 6th century BC, later Persian, Ion, etc. must have been a source of inspiration for many Anatolian cultures. From this situation, it is unthinkable that the geography of Aeolis, from the gates of Lydia opening to the Aegean, would not be affected.

In the region stretching from Smyrna in the south to Pergamon in the north, the place where tumuli are most frequently encountered is the Larisa-Kyme line. Although the tumuli in this line have not been studied holistically academically, the Larisa examples are relatively mentioned. The largest of these tumuli in the Hermos plain is $55 \mathrm{~m}$ in diameter. However, there are also examples of very small diameters. When looking at the Larisa tumuli in general, there is no standard. Their average diameter is $4-5 \mathrm{~m}$ in the middle of the tumuli, there is usually a cist for burial. This coffin is surrounded by oval or square shaped walls. Afterwards, soil was piled up in the shape of a cone over the graves. Researchers say that they belong to the 5 and 4th century BC, especially based on the masonry ${ }^{15}$. Another tumulus located in Kyme, which is the largest Aeolian settlement in the north of Larisa, is Kelebek Tepe. This tumulus is also the only one excavated in the region. It is said that the tumulus, which can be said to be large, was used at least twice and was built around $500 \mathrm{BC}$ at the latest. When we look at the structure of the tumulus, it is seen that it has a classical structure with masonry walls ${ }^{16}$. It seems that the tumulus tradition reached the region in a short time in the 6th century BC. Perhaps through the later Persians, this influence increased even more from the 5th century BC. The tumuli found around Myrina and Grynaion show that this tradition was continued in the region until the Hellenistic Period. For example, the Kayaalan Tumulus was built by piling soil on top of a vaulted structure made of cut stones. It was thought that the tumulus with a diameter of $3.70 \mathrm{~m}$ should have been $10-12 \mathrm{~m} \mathrm{high}^{17}$. On the other hand, just east of Kyme and Myrina, the Tisna tumuli have a unique feature, as demonstrated by tumulus No. 1.

It is understood that the tumulus, which was identified in the west of Tisna/Sarıkale Tepe by the team led by E. Erdan in 2018, has been destroyed over the ages. The tumulus was formed by carving a small rocky hill in the rocky geography of Sarkale Tepe (Fig.2). Accordingly, the rock mass was carved in the form of two rooms approximately $6 \mathrm{~m}$ long, $2 \mathrm{~m}$ wide and $2 \mathrm{~m}$ high, and a dromos was built at the entrance by carving the rock (Fig.3). After the burial, the rock was covered first with large stones and then with soil in the form of a small mound (Fig.4). Thus, the structure is in the form of a tumulus when viewed from the outside and a rock tomb when entered. That's why we found it more accurate to call this tomb "Rock-Carved Tumulus". As a matter of fact, the structure is very different from the classical Tumulus examples. The entrance to the tomb/dromos is in the south/south-east direction (Fig.5-6). After the corridor/dromos formed by carving the bedrock with a length of $2.90 \mathrm{~m}$, a height of $1.70 \mathrm{~m}$ and a

\footnotetext{
${ }^{15}$ Saner- Külekçi- Mater 2017, 59.

${ }^{16}$ Verger-Pace-Jolivet 2013, 245-249.

${ }^{17}$ Özdemir-Çekilmez 2018, 262-63.
} 
width of $1.10 \mathrm{~m}$, the tomb door is reached. The entrance opening in the form of saddle roof is $1.23 \mathrm{~m}$ high and $76 \mathrm{~cm}$ wide. Entering through this door, a front room $2.40 \mathrm{~m}$ long and $2.27 \mathrm{~m}$ wide is encountered (Fig.7). The floor of the room has at least half a meter of filling caused by destruction and soil filling. The height of the room should be approximately $2 \mathrm{~m}$. At the end of the antechamber, a second door is encountered, which leads to the main room and has a door slot. This door jamb is $90 \mathrm{~cm}$ wide, $1.30 \mathrm{~m}$ high and $60 \mathrm{~cm}$ thick. Passing through the second door, the main room is $2.90 \mathrm{~m}$ long, $1.97 \mathrm{~m}$ wide and approximately $2 \mathrm{~m}$ high again due to the filling (Fig.8). The ceiling part of the rooms that make up the interior of the tomb was carved in the form of a cradle roof. Thick chisel marks related to chipping of the rock are seen on both the sides and the top (Fig.9). According to our findings, the rectangular blocks in both the first and second rooms, most of which were fragmented, point to a kline in each room. The klines formed from these smooth cut stone blocks measuring $70 \mathrm{X} 55 \mathrm{X} 18 \mathrm{~cm}$ have been destroyed. It is understood that this destruction was not carried out in ancient times, but in the near past. On the other hand, it is interesting that the $43 \mathrm{X} 52 \mathrm{~cm}$ wide and $40 \mathrm{~cm}$ deep niche adorning the west wall of the second room was not damaged much.

While evaluating the Tisna tomb, it is necessary to evaluate the other rock tombs nearby. Myrina is especially important in this regard. These tombs, called "Rock Carved Tombs", are entered with a 2-3m long dromos by carving the tuff rock, like the Tisna example. Their difference is that they have a single room and a vaulted roof form. However, the bones and klines found showed that they were family tombs. The widths of the Myrina burial chambers vary between $5 \mathrm{~m}$ and $1.80 \mathrm{~m}^{18}$. In this respect, it is possible to compare the two-room Tisna tomb with the largest of the Myrina examples. In addition, the example of Tisna is more elaborate than any of them in terms of architecture. Another and much more nearly example is found on the northeastern slope of Sarikale Tepe. The tomb, carved into the steep rock at a height of $2.68 \mathrm{~m}$ from the walk plane, measures $2.16 \mathrm{X} 1.09 \mathrm{~m}$. The entrance part of the tomb is in the form of a cradle, as in our example, and the burial part is in the shape of a dome, as in the Myrina examples. There is no kline in the burial chamber. The height of the tomb is 1.30 meters on average. However, the tomb has a much more elaborate workmanship compared to other rock tombs in the region. Hence the tomb has been dated in $4 / 3$ th centuries $\mathrm{BC}^{19}$. When compared in terms of workmanship, the rock tumulus number 1 was built much earlier than this tomb. Another very important find of the Tisna No. 1 Rock-Carved Tumulus is the inscription on a rectangular block at the entrance of the second room (Fig.10-11). In our opinion, this block belongs to the kline in the second room. There is a Greek inscription in two lines on the $78 \times 34 \times 23 \mathrm{~cm}$ size block:

\footnotetext{
${ }^{18}$ Özdemir-Çekilmez 2018, 255-60.

${ }^{19}$ Aydoğmuş 2019, 421-439.
} 


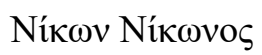

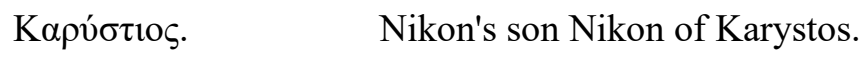

The detailed work done by Erdan and Aydaş on this inscription shows that Nikon was born in Karystos of Euboia, and later came to Tisna and died there. As a matter of fact, the text was not written in the Aeolis dialect. In addition, the inscription is dated to the 4 th century $\mathrm{BC}^{20}$. In fact, the Peace of Kallias $^{21}, 449$ BC, should be a Terminus Ante Quem for the tomb of a non-citizen Euboian at Tisna. So, it is difficult for Nikon to have lived in Tisna before this date. Therefore, it does not seem possible to date his grave earlier than the last quarter of the 4th century BC. In this respect, the dating suggested by Erdan and Aydaş is a logical inference.

\section{Conclusion}

Nikon's Rock-Carved Tumulus is one of 47 tumuli around the acropolis of Tisna. And they, in general, must be of the "Rock-Carved Tumulus" type, unlike the classical tumuli. In other words, this type is a mixed type created by combining tumulus and rock tombs. It is evident that there are many tombs of this type at Tisna and await investigation. Considering all the above considerations it can be assumed that this type of burial began in the second half of the 5th century BC at the earliest for Tisna and continued throughout the 4th century BC. Nikon's tomb, on the other hand, shows archaic features, especially with its polygonal walls that make up the dromos, but the rektogonal blocks and inscription in the rooms show the characteristics of the 4 th century. So, in our opinion, the most likely date for Nikon's Rock-Carved Tumulus is the first quarter of the 4th century BC.

${ }^{20}$ Aydaş-Erdan 2019, 197-206.

${ }^{21}$ Mansel 1995, 305; Tekin 2008, 102. 


\section{Bibliography}

Aydaş ve Erdan 2019 Aydaş, M., \& Erdan, E., “Aiolis Bölgesi’nden Yeni Bir Yazıt ve Buluntu Yeri Üzerine", Phaselis V, 197-206.

Aydoğmuş 2019 Aydoğmuş, N., “Tisna-Sarıkale Tepe Kaya Mezarı”, Doğudan Batıya 70. Yaşında Serap Yaylalı'ya Sunulan Yazılar, A.Ören, E.Erdan (ed.), Ankara, 421-438.

Baughan 2010 Baughan, E.P. "Lydian Burial Customs / Lidya Gömü Gelenekleri.” In Lidyalılar ve dünyalarl / The Lydians and Their World, edited by N.D. Cahill, 273-304, Istanbul.

Conze 1910 Conze, A., "Eine Griechhische Stadt”, JdI XXV, 1-12.

Erdan 2019 Erdan, E, Tisna I İlk Araştırmalar ve Gözlemler, İstanbul.

Erdan-Aydoğmuş 2019 Erdan, E., - Aydoğmuş N., “Aiolis’te Yeni Bir Arkaik Dönem Nekropolü Hakkında İlk Gözlemler: Tisna-Sarıkale Tepe Güney Yamacı”, ATASOBET 23/3, 1131-1158.

Mansel 1995 Mansel, A. M., Ege ve Yunan Tarihi, Ankara.

Özdemir-Çekilmez 2018 Özdemir, E.-Çekilmez, M., "Myrina Antik Kenti Nekropolü, Mezar Tipleri ve Ölü Gömme Gelenekleri”, Uluslararası Aliağa ve Çevresi-Aiolis Bölgesi-Arkeoloji ve Disiplinlerarası Araştırma Sempozyumu, (Semtember 27-28), İzmir, 243-278.

Özşahin -Eroğlu 2019 Özşahin, E., Eroğlu, İ., Aliağa Coğrafya Atlası, İzmir.

Ronchetta 2016 Ronchetta D., "The Significance of the Tumulus Burial among the Funeral Buildings of Hierapolis of Phrigia” Eds. O. Henry - U. Kelp. Tumulus as Sema: Space, Politics, Culture and Religian in the First Millenium BC., Berlin, 513-587.

Sams 2007 Sams G. K., “Gordion ve Frigler”, Friglerin Gizemli Uygarlığı, İstanbul, 49-58.

Saner- Külekçi- Mater 2017 Saner, T.- Külekçi, I.- Mater, G., Architectural Survey at The Necropolis of Larisa(Buruncuk), İstanbul.

Sayce 1882 Sayce, A. H., "Explorations in Aeolis", The Journal of Hellenic Studies Vol. 3, 218-227.

Schuchhardt 1887 Schuchhardt, C., "Vorläufiger Bericht über eine Bereisung der pergamenischen Landschaft", Sitzungsberichte der Koeniglich Preussischen Akademie der Wissenschaft zu Berlin, 1207- 1214. 
Schuchhardt 1912 Schuchhardt, Historische Topographie der Landschaft. Stadt und Landschaft von Pergamon. Altertümer von Pergamon 1.1, 61-143.

Tekin 2008 Tekin, O., Eski Yunan ve Roma Tarihine Giriş, İstanbul.

Vardar 2018 Vardar, S., "Sedimantolojik ve Mikropaleontolojik Verilerle Güzelhisarçayı Kıyı Ovasının Holosen Paleocoğrafyası”, Doğu Coğrafya Dergisi, 23/39, 131-148.

Verger-Pace-Jolivet 2013 Verger, S. - Pace, R.- Jolivet, V., "La Fouille du Kelebek Tepe, un Grand Tumulus Tardo-archaïque dans la Nécropole nord de Kymè d'Eolide", Anatolia Antiqua. Revue Internationale d'archéologie Anatolienne 21, 245-260. 


\section{List of Figures}

Fig.1. The place of Tisna in the geography of Aeolis.

Fig.2. Nikon's Rock-Carved Tumulus.

Fig.3. Plan of the Tomb.

Fig.4. Cross Section Drawing of the Tomb.

Fig.5. Dromos.

Fig.6. Dromos

Fig.7. Front Room

Fig. 8. Second Room.

Fig. 9. Front Room Ceiling and Outside View.

Fig. 10. Stone with Inscription

Fig. 11. Stone with Inscription, Detailed.

Fig. 12. Polygonal Wall of the Dromos. 


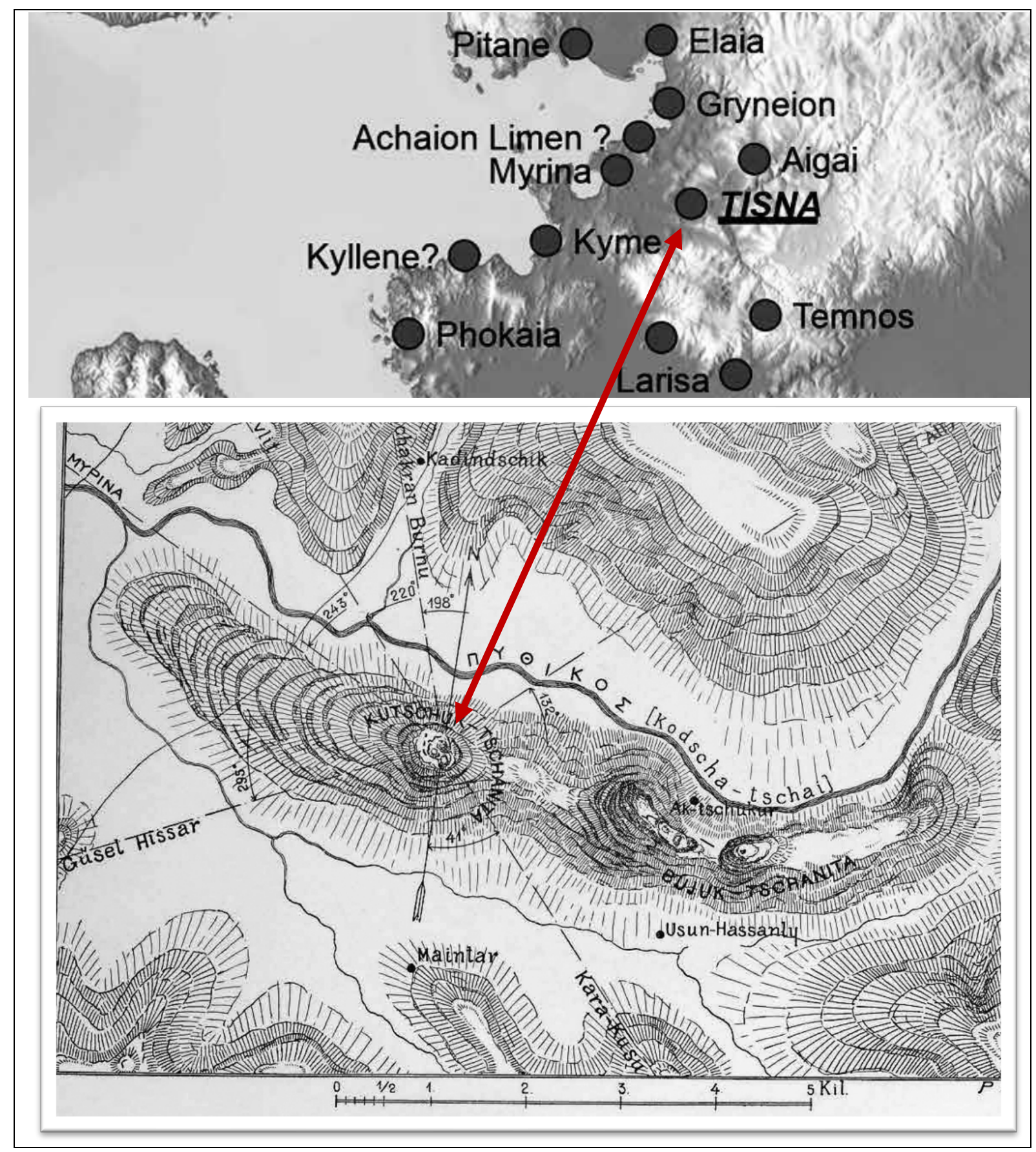

Fig.1 


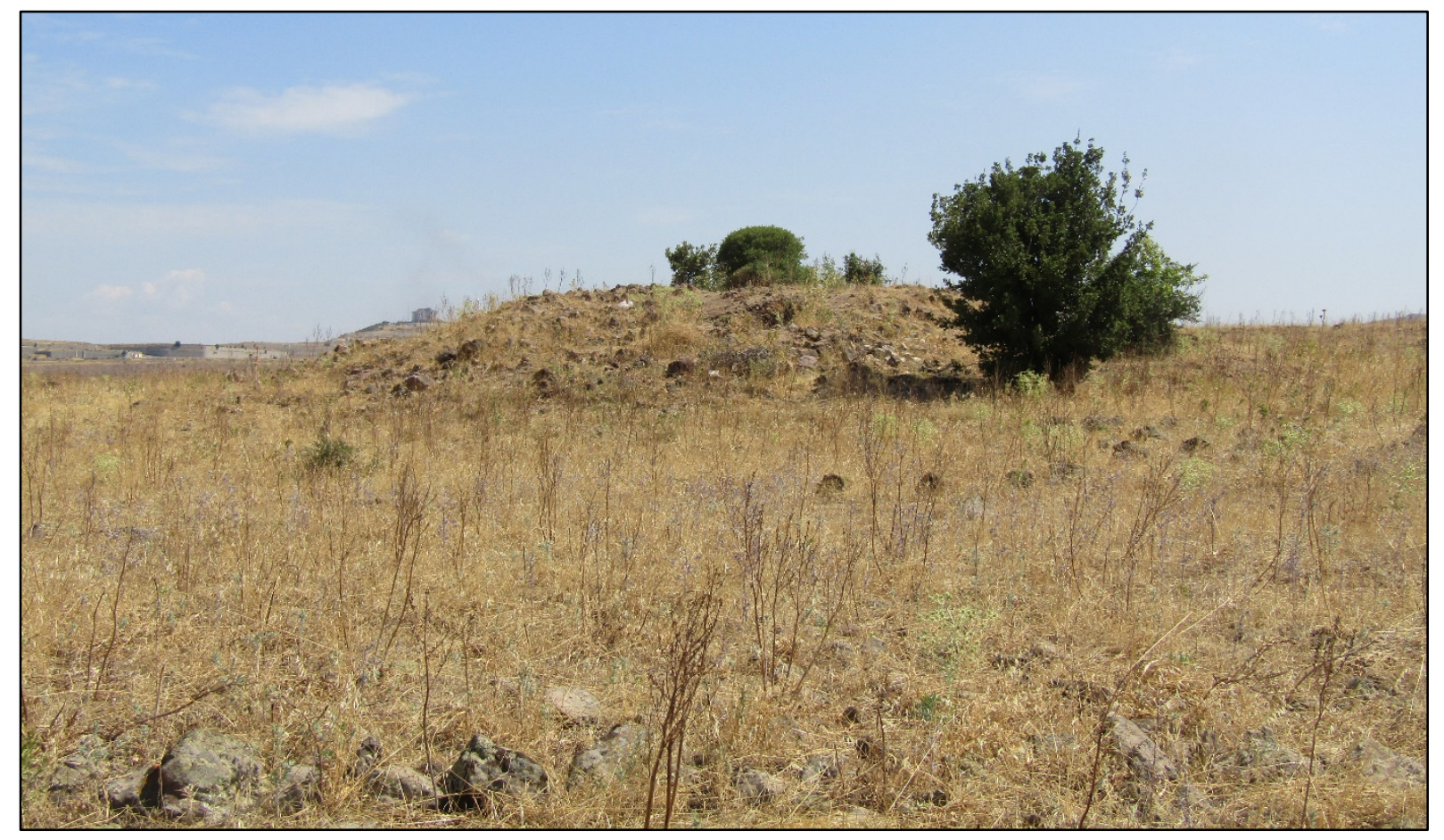

Fig.2

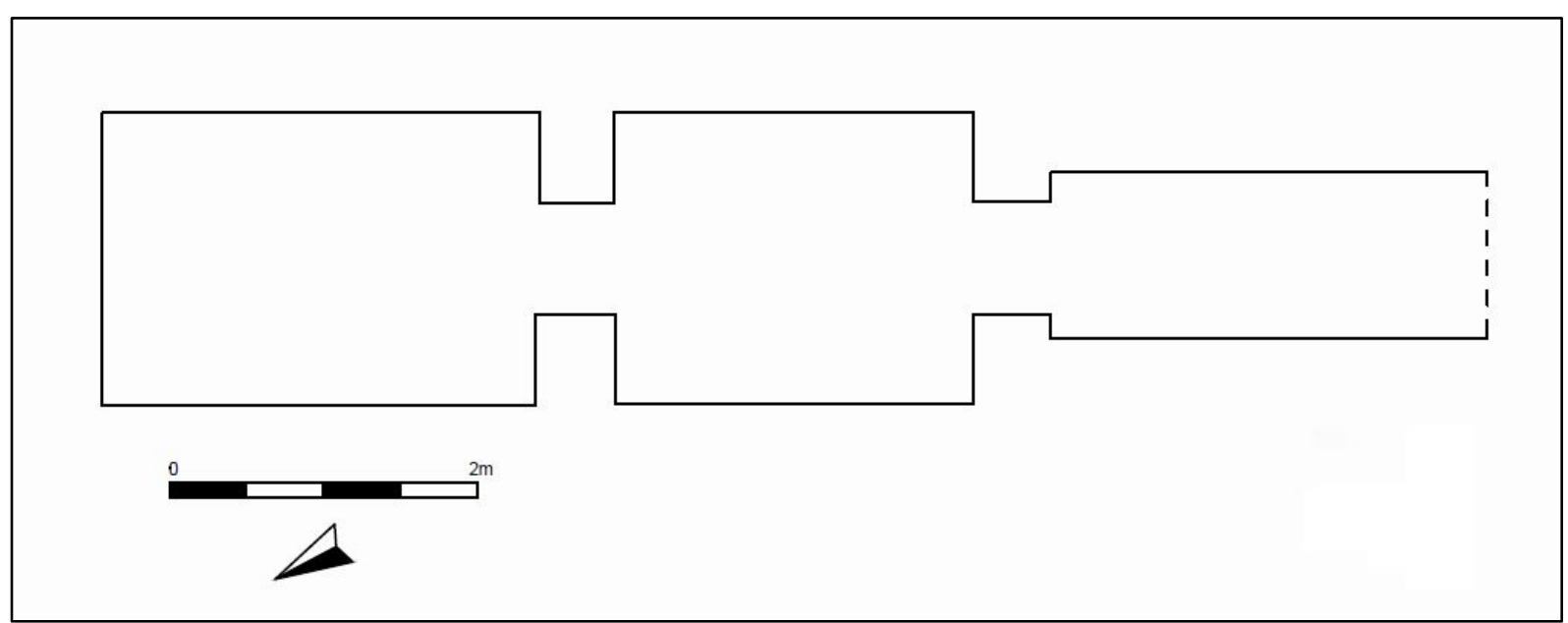

Fig.3

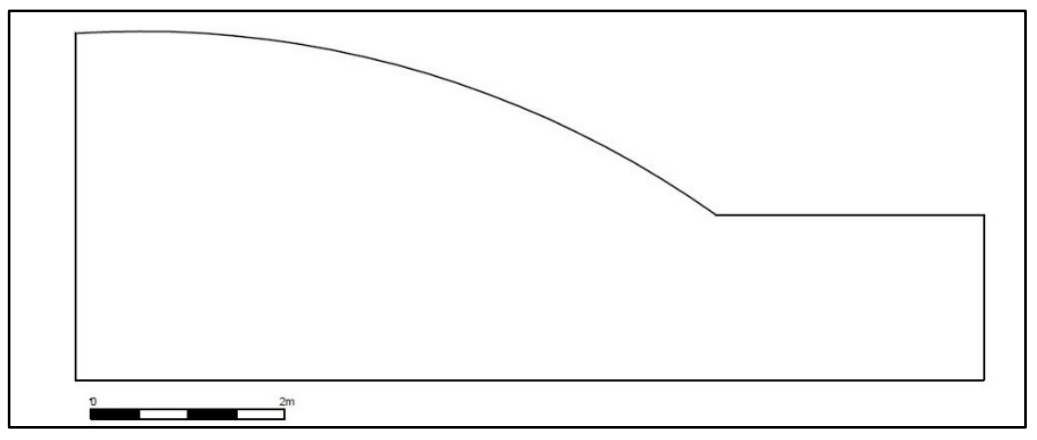

Fig.4 


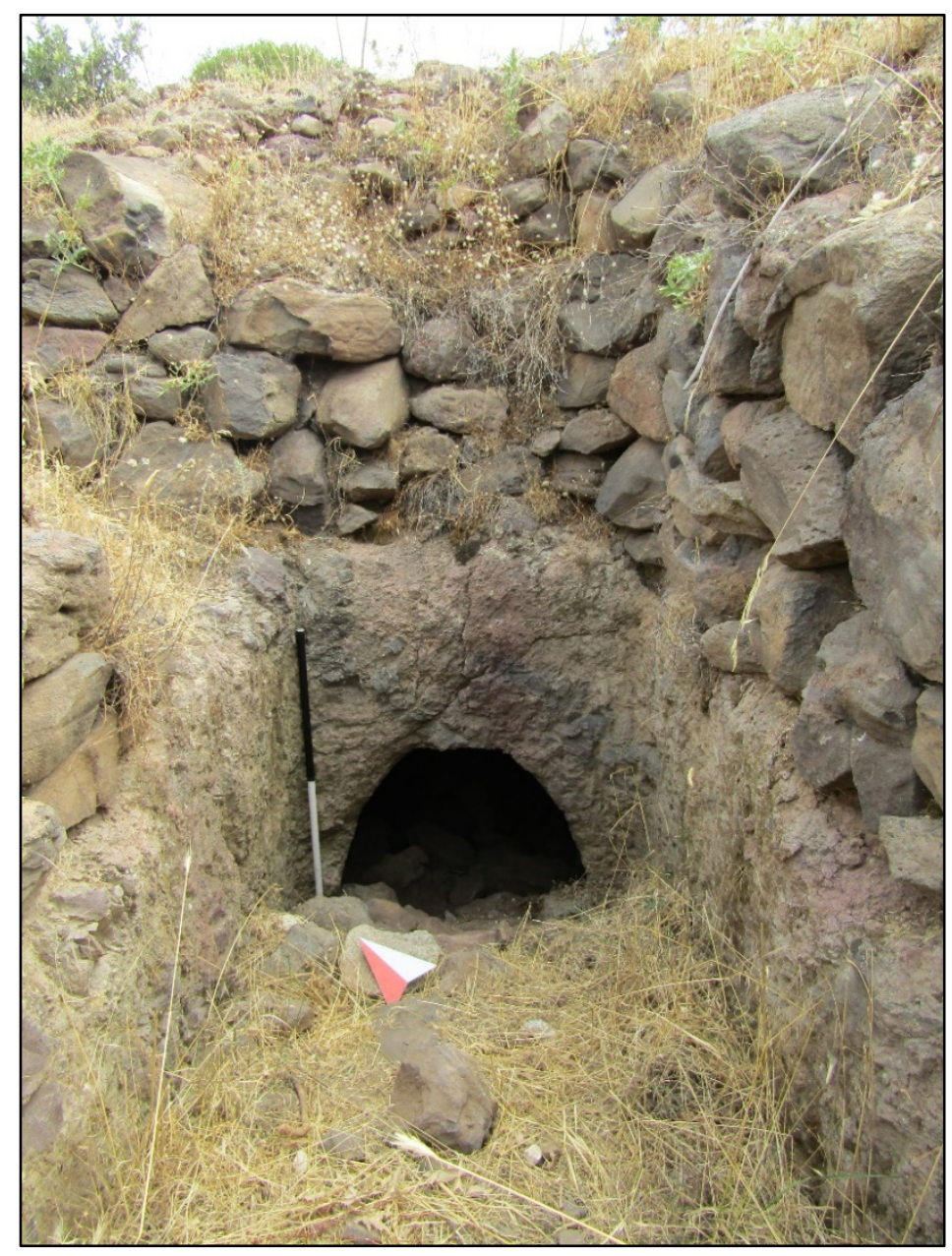

Fig.5

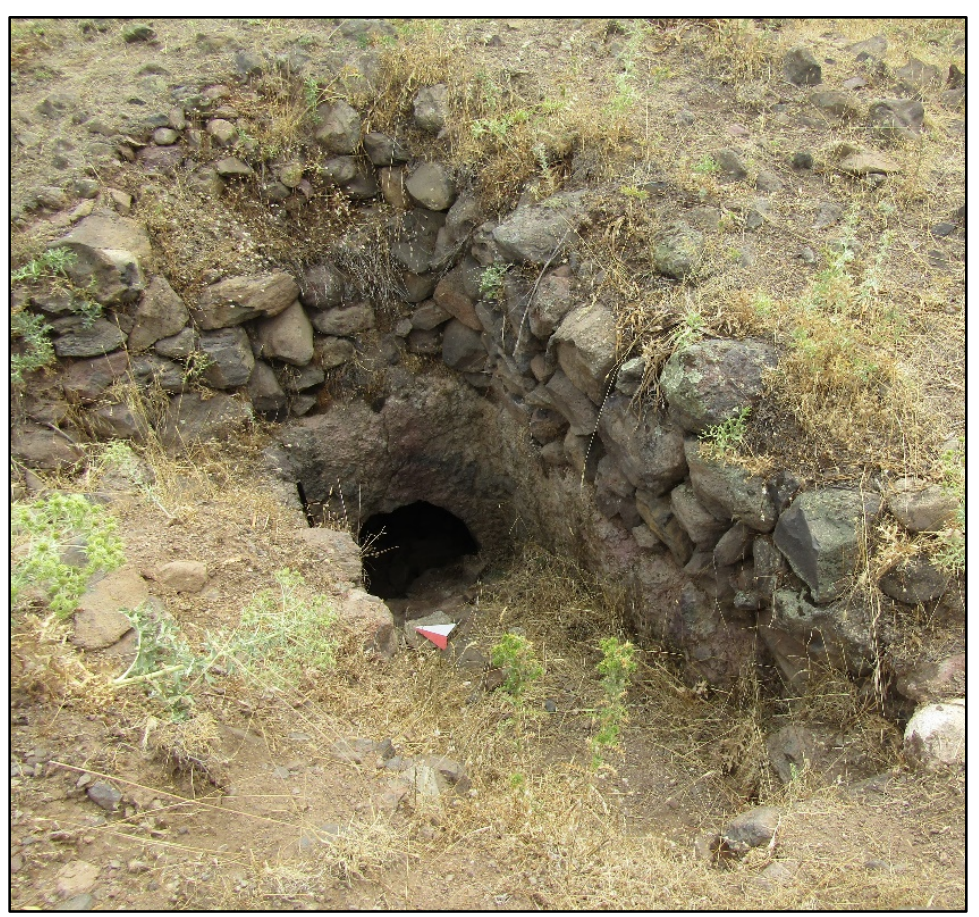

Fig.6 


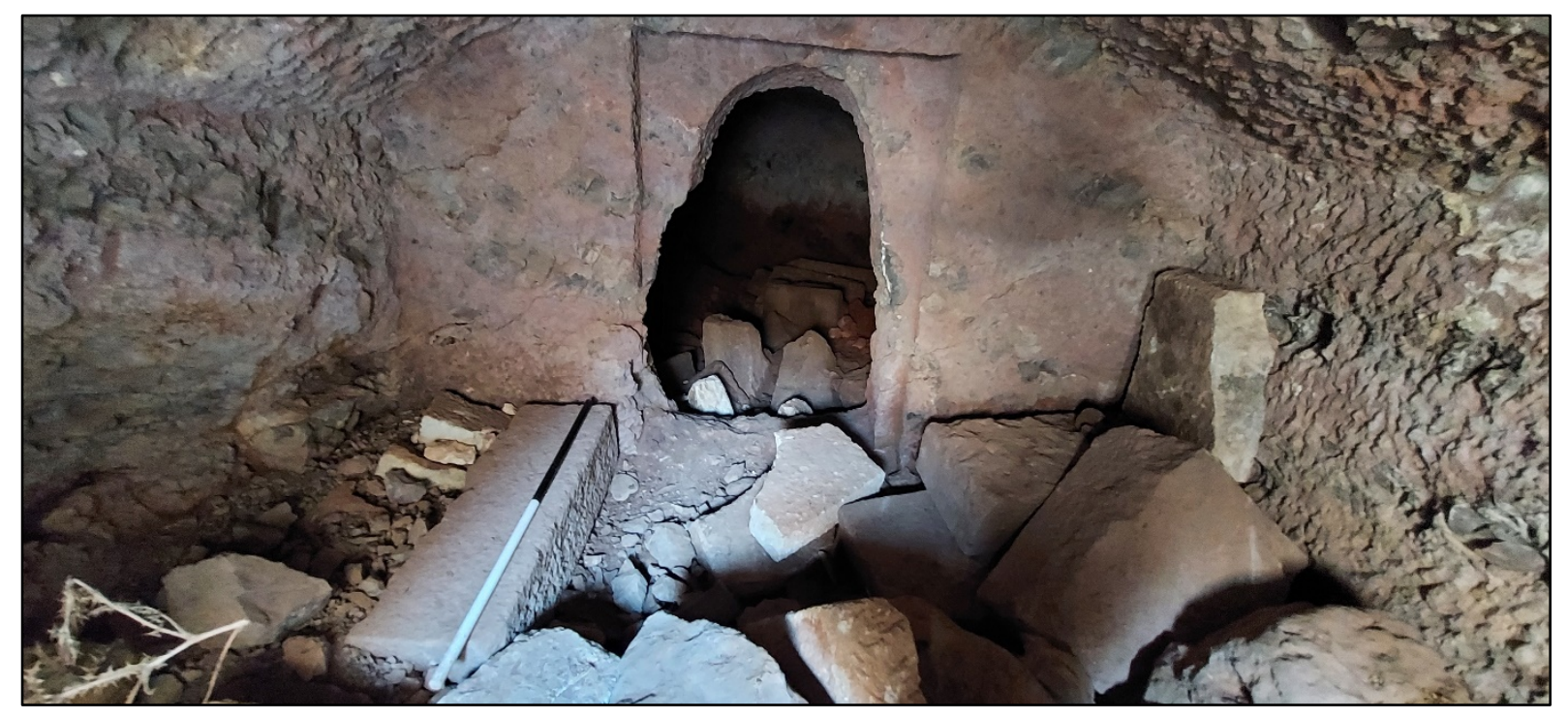

Fig.7

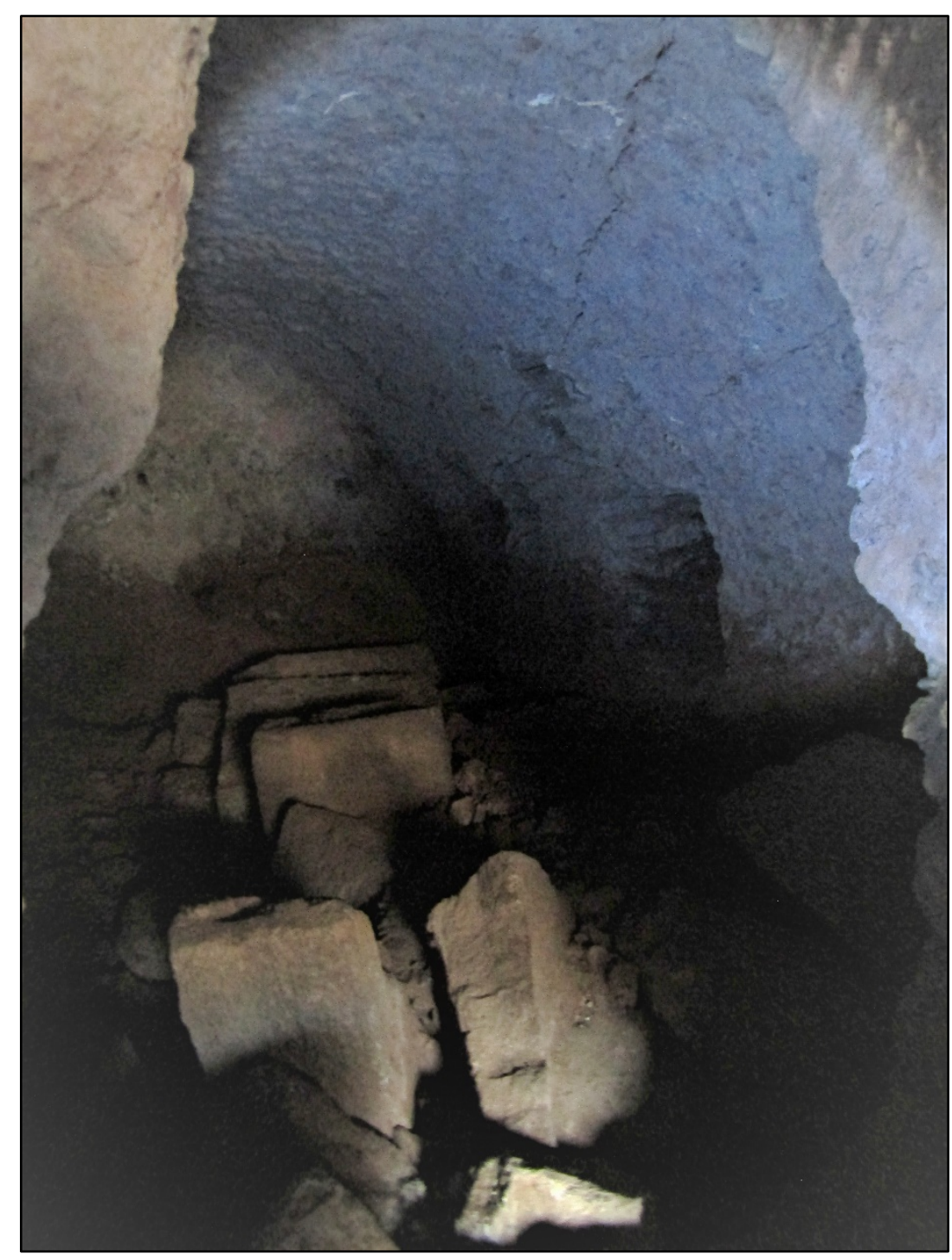

Fig. 8 


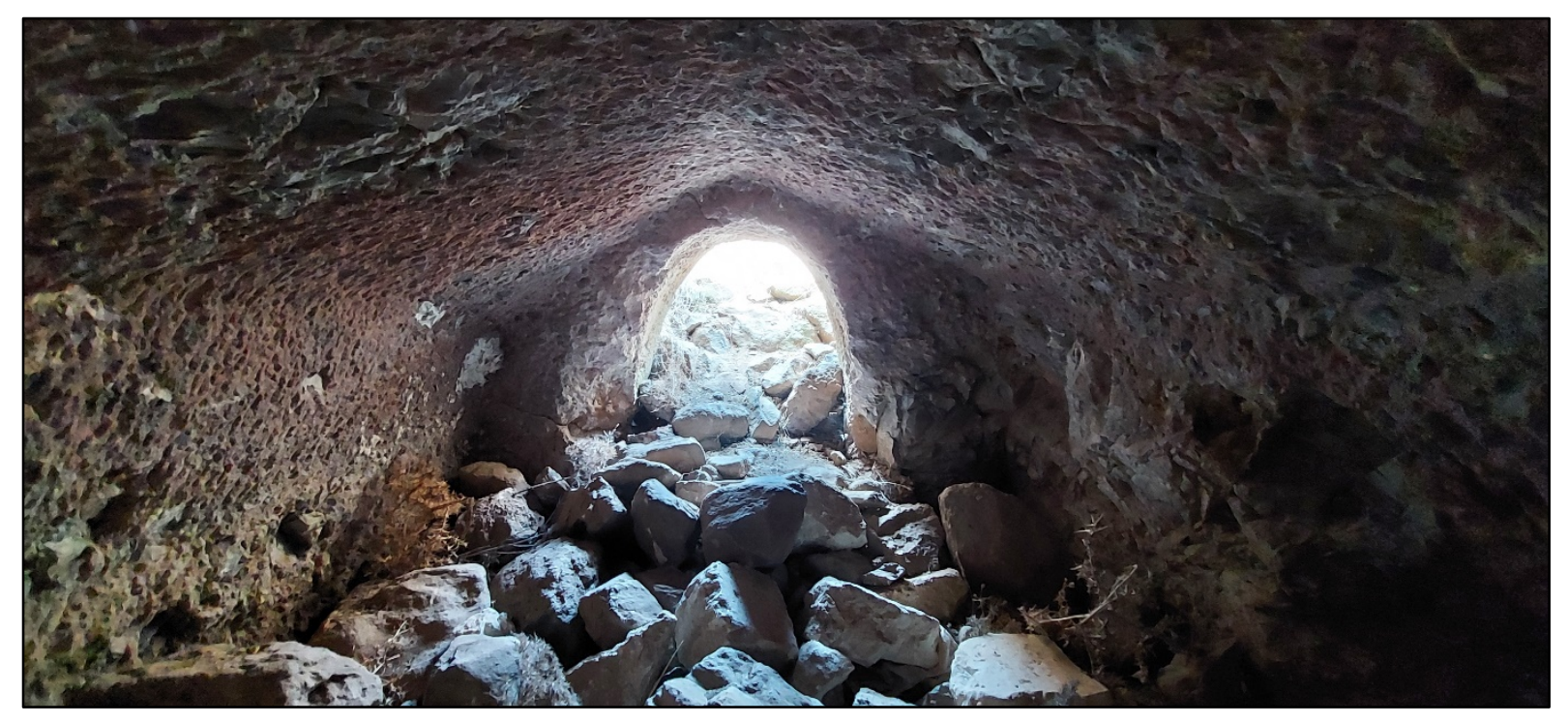

Fig.9

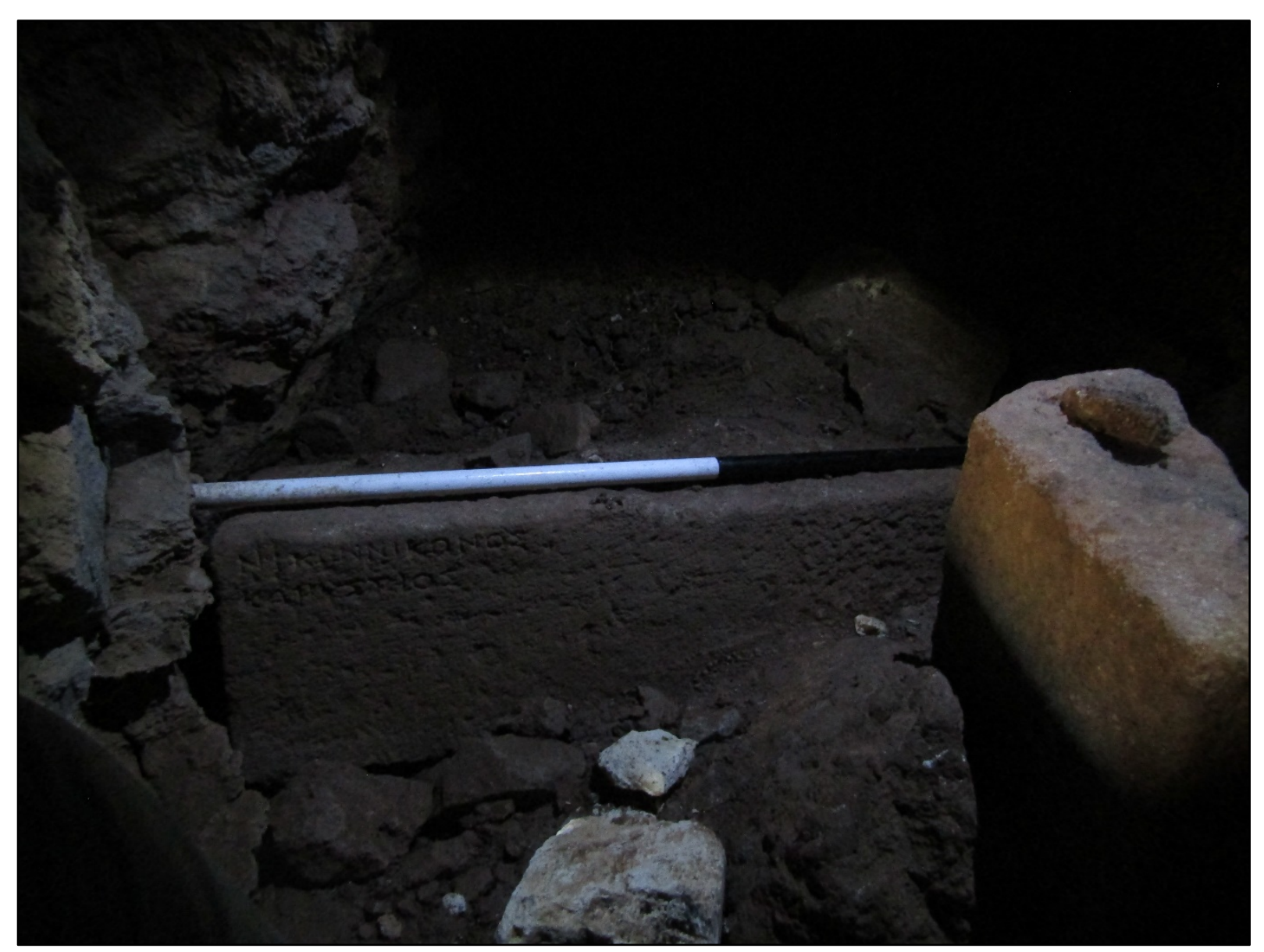

Fig.10 


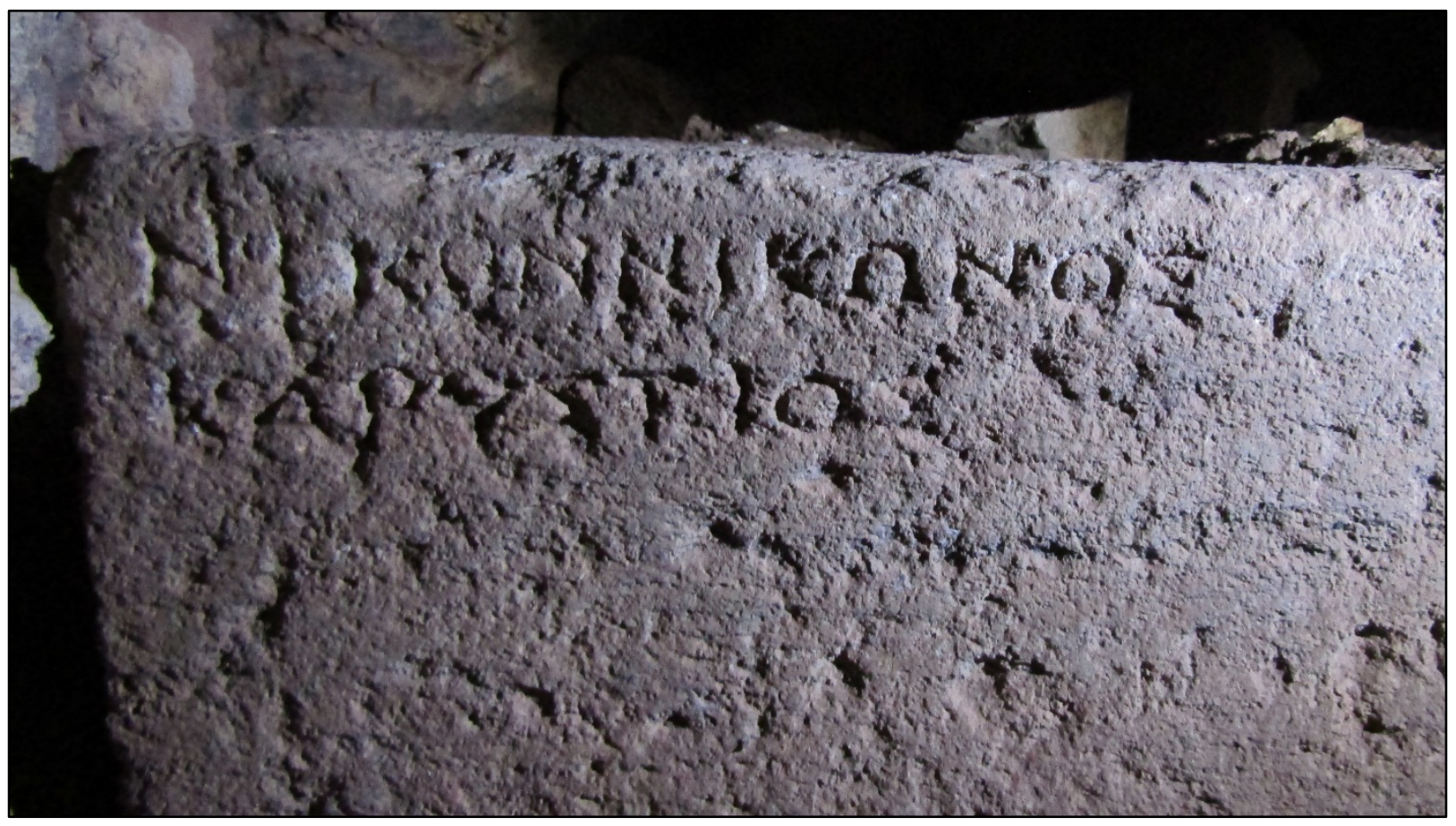

Fig.11

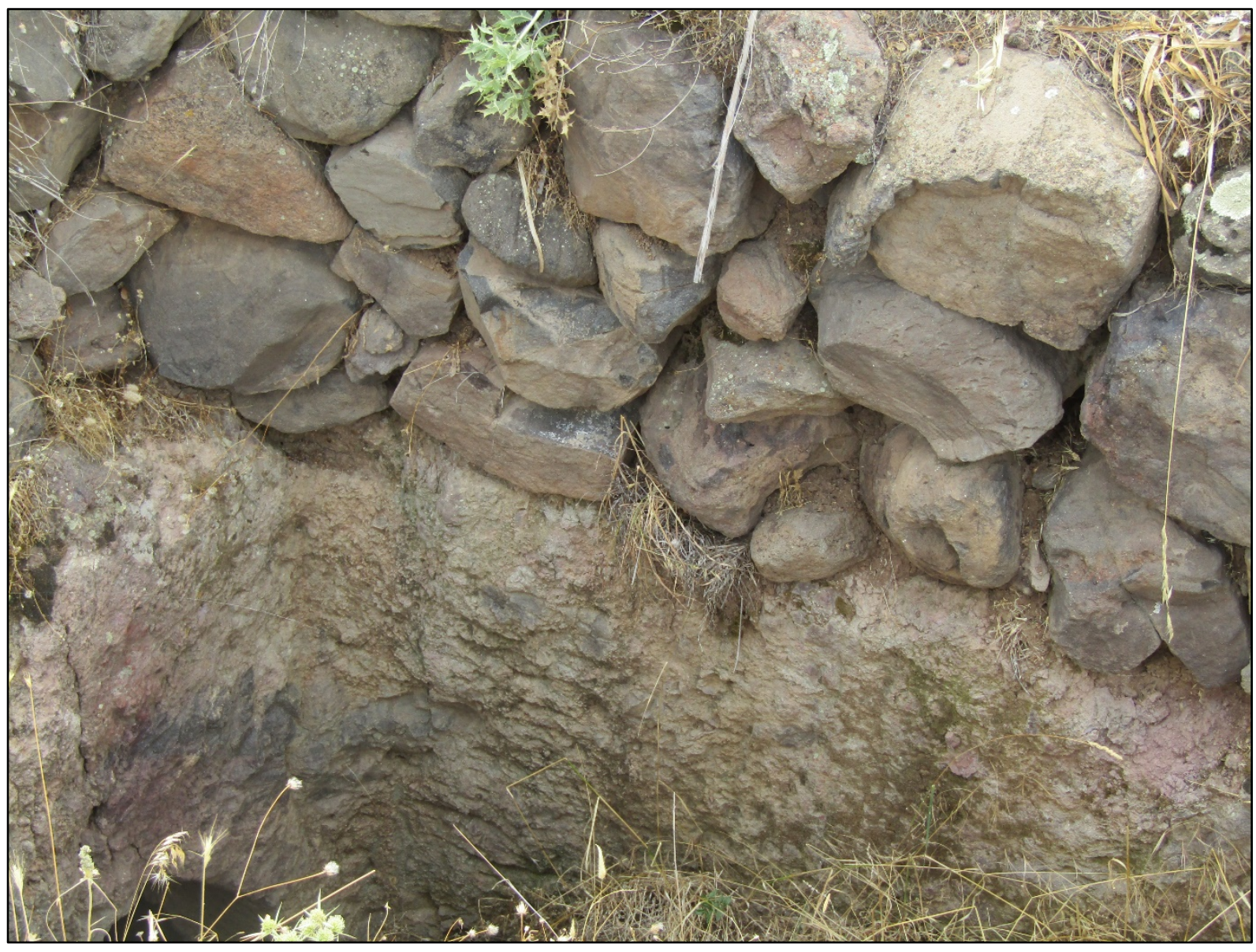

Fig. 12 